\title{
JOSÉ LUÍS JOBIM DE SALLES FONSECA: O SENHOR DONO DO BAILE
}

Se José Luís Jobim de Salles Fonseca tivesse sido meu professor, eu o homenagearia por isto. Se tivesse sido meu orientador, também seria uma oportunidade para dedicar uma homenagem, mas ele não foi nem uma coisa, nem outra, no sentido homônimo da palavra. O ofício de professor e orientador se deu pela boa conversa, as indicaçóes a seguir e o estímulo constante à carreira. Já conhecia Jobim de ouvir, de ver, de ler. Mas o reconheci mesmo por ocasiáo de umas férias que ele e Bethania passaram em Belém, não lembro se em janeiro de 2004 ou 2005. Na ocasião, fomos a Icoaraci, no bairro do Paracurí, comprar cerâmica. Passamos a tarde a escolher as peças e depois fomos saborear um bom caranguejo, como era o desejo da Bethania. Na época, Jobim era o presidente da Associaçáo Brasileira de Literatura Comparada (ABRALIC) e diretor do Instituto de Letras da Universidade do Estado do Rio de Janeiro (UERJ). Como àquela altura eu pouco prestava atenção a quem ocupava os cargos no mundo acadêmico, esbocei um comentário sobre o último evento da Associação e, logo depois, soube que estava diante do atual presidente. Felizmente, os anos que seguiram após aquele só consolidaram uma amizade e a parceria acadêmica.

Neste momento, tenho, cá para mim, que a melhor homenagem seria comentar a vasta obra, a história acadêmica nas Instituiçôes do Rio de Janeiro, suas incursôes internacionais, mas prefiro lembrar as liçóes na prosa informal. A presença do amigo e do profissional Jobim foi muito importante no momento em que precisávamos submeter um importante projeto à CAPES e necessitávamos de uma Instituição parceira. Na busca pela parceria, após receber algumas recusas, conversei com Marisa Lajolo, que me disse: "procure o Jobim, Germana. Ele apoiará o projeto". Bingo! Conversamos informalmente em São Paulo, por ocasião da ABRALIC, e elaboramos o projeto juntos, com correspondência por e-mail. Submetemos o projeto PROCAD-AF e tivemos êxito, o que se configurou em uma importante contrapartida acadêmica entre a Universidade Federal do Pará (UFPA) e a UERJ, com visíveis resultados, tanto na produção, quanto na formação de recursos humanos. Os resultados desse projeto foram consolidados com publicaçôes de coletâneas organizadas pelos membros da equipe, as quais, certamente, contribuíram muito para a melhoria do Programa de Letras da UFPA e, principalmente, para a condução da vida acadêmica dos nossos alunos, sendo que muitos já seguem no Curso de Doutorado, alguns na UERJ. Coordenávamos o projeto eu, pelo lado da UFPA, e Roberto 
Acízelo, pela UERJ. Não refuto em afirmar que a mediação das partes era promovida pelo nosso amigo em comum, Jobim. Durante esses anos, entre muitas visitas suas à UFPA e algumas nossas à UERJ, Jobim foi um mestre. Aprendi muito. Suas qualidades passam da magnífica elegância para o trato pessoal, para a objetividade em propor soluçóes aos problemas que parecem insolúveis, para a organização na condução da vida acadêmica. Lembro-me que, quando fui assumir a coordenaçáo do Programa de Letras na UFPA, Jobim recomendou a mim e a minha parceira de trabalho que conduzíssemos a gestáo para todos, indistintamente, e que a condução do trabalho acontecesse de forma diferenciada, para que a gestáo ficasse marcada. Quanto à primeira indicação, cumprimos a rigor, mas em relação à segunda, se o trabalho que realizamos nos dignificou, a história dirá. Além dessas recomendaçóes, devo ressaltar o apoio irrestrito de Jobim para que a UFPA abraçasse a ABRALIC. Durante toda a gestáo, Jobim, com sua expertise, seja acadêmica, seja para a condução de decisóes políticas, foi um fiel amigo e grande colaborador.

Acredito que a vida, regida por caminhos aleatórios, aproxima-nos de boas e más experiências com o ser humano. $\mathrm{Na}$ condução desses caminhos surgem aqueles a quem vale dirigir nossa atençáo e que merecem homenagens, por serem pessoas especiais. Essas são pessoas exclusivas, particulares, não apenas pela construção de uma carreira, mas porque em relaçáo a elas é possível, ao lado da história profissional, juntar qualidades diversas que, somadas, compóem seres humanos especiais. Esta é uma oportunidade para que eu possa expor a admiração que tenho ao Jobim, cuja amizade me orgulha muito. Parece óbvio ressaltar que a fidelidade, a lealdade, o compromisso, a generosidade, a erudição, a simplicidade, a tolerância, a paciência, entre outras qualidades, são suficientes para patentear o homenageado. Mas não são. Jobim é um mestre, e a um mestre devemos honras, prestígio, mas principalmente gratidão. Por isso, é justo e valoroso que Jobim receba as páginas reunidas, esboços da nossa admiração e amizade, que jamais poderão ser traduzidas em papel e tinta, pois, de tão fecunda relação de afeiçáo, as linhas são provisórias para aquilatar toda a consideraçáo a quem compartilhou liçóes e a quem fez do dedo de prosa a melhor situaçáo para partilhar seus conhecimentos. Viva Jobim!!! Viva a nova idade que escreve uma história gloriosa de benfeitorias e conquistas sublimes. A vida, quando construída para o bem, sem egoísmos e com abundante generosidade, resulta em afetos, amizades e admiração, sentimentos que todos os que partilham dessa coletânea alimentam em relação ao bravo Jobim. 